\title{
Functional group composition of ambient and source organic aerosols determined by tandem mass spectrometry
}

\author{
J. Dron ${ }^{1,{ }^{*}}$, I. El Haddad ${ }^{1}$, B. Temime-Roussel ${ }^{1}$, J.-L. Jaffrezo ${ }^{2}$, H. Wortham ${ }^{1}$, and N. Marchand ${ }^{1}$ \\ ${ }^{1}$ Université d'Aix-Marseille -CNRS, Laboratoire Chimie Provence (UMR 6264), Équipe Instrumentation et Réactivité \\ Atmosphérique, 3 place Victor Hugo, 13331 Marseille Cedex 3, France \\ ${ }^{2}$ Université Joseph Fourier - Grenoble 1 -CNRS (UMR 5183), Laboratoire de Glaciologie et Géophysique de \\ l'Environnement, 54 Rue Molière, BP 96, 38402 St. Martin d'Hères Cedex France \\ *now at: Laboratoire d'Analyses Radiochimiques et Chimiques (Bât. 152), CEA Cadarache, 13108 St.-Paul-lez-Durance, \\ France
}

Received: 8 December 2009 - Published in Atmos. Chem. Phys. Discuss.: 13 April 2010

Revised: 22 July 2010 - Accepted: 24 July 2010 - Published: 3 August 2010

\begin{abstract}
The functional group composition of various organic aerosols $(\mathrm{OA})$ is investigated using a recently developed analytical approach based on atmospheric pressure chemical ionisation-tandem mass spectrometry (APCIMS/MS). The determinations of three functional groups contents are performed quantitatively by neutral loss (carboxylic and carbonyl groups, $\mathrm{R}-\mathrm{COOH}$ and $\mathrm{R}-\mathrm{CO}-\mathrm{R}^{\prime}$ respectively) and precursor ion (nitro groups, $\mathrm{R}-\mathrm{NO}_{2}$ ) scanning modes of a tandem mass spectrometer. Major organic aerosol sources are studied: vehicular emission and wood combustion for primary aerosol sources; and a secondary organic aerosol (SOA) produced through photooxidation of $o$-xylene. The results reveal significant differences in the functional group contents of these source aerosols. The laboratory generated SOA is dominated by carbonyls while carboxylics are preponderate in the wood combustion particles. On the other hand, vehicular emissions are characterised by a strong nitro content. The total amount of the three functional groups accounts for $1.7 \%$ (vehicular) to $13.5 \%$ (o-xylene photooxidation) of the organic carbon. Diagnostic functional group ratios are then used to tentatively discriminate sources of particles collected in an urban background environment located in an Alpine valley (Chamonix, France) during a strong winter pollution event. The three functional groups under study account for a total functionalisation rate of 2.2 to $3.8 \%$ of the organic carbon in this ambient aerosol, which is also domi-
\end{abstract}

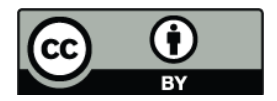

Correspondence to: J. Dron (julien.dron@cea.fr) nated by carboxylic moieties. In this particular case study of a deep alpine valley during winter, we show that the nitroand carbonyl-to-carboxylic diagnostic ratios can be a useful tool to discriminate sources. In these conditions, the total OA concentrations are highly dominated by wood combustion OA. This result is confirmed by an organic markers source apportionment approach which assess a wood burning organic carbon contribution of about $60 \%$. Finally, examples of functional group mass spectra of all aerosols under study are presented, and additional perspectives offered by the mass spectra in terms of OA characterisation are discussed.

\section{Introduction}

It is now well known that climate and air quality are significantly affected by the composition of the atmospheric organic aerosol (OA) (Kanakidou et al., 2005; IPCC, 2007). However, in spite of the wide range of analytical techniques employed, our knowledge and understanding of the physicochemistry, formation mechanisms, sources, and toxicity of the atmospheric OA are still very incomplete (Fuzzi et al., 2006). The $\mathrm{OA}$ is a complex environmental matrix composed of thousands organic compounds including a significant fraction of high molecular weight compounds (Pio et al., 2001; Graber and Rudich, 2006). Its chemical characterisation is generally only achieved at best for $20 \%$ by mass using molecular analysis techniques, mainly owing to the insufficient resolution and identification capabilities offered by chromatographic systems (Cappiello et al., 2003; Hamilton

Published by Copernicus Publications on behalf of the European Geosciences Union. 
et al., 2005; Decesari et al., 2006). On the other hand, total carbon analysis and aerosol mass spectrometer analysis (AMS) provide a complete description of the POM, but only limited information relative to the chemical composition (Ruellan and Cachier, 2001; Cao et al., 2005; Lanz et al., 2008). Although huge progress has been accomplished during the last decade regarding OA chemical characterisation, analytical efforts should be pursued to improve the chemical compositional data set and reduce the uncertainties related to the organic fraction chemistry of atmospheric aerosol. In particular, functional group analysis appears as a valuable approach in order to better assess the processes involved in new emerging issues regarding OA, such as chemical aging of both primary and secondary OA (Donahue et al., 2009; Hallquist et al., 2009).

The usual analytical technique for functional group analysis is Fourier-Transform InfraRed spectroscopy (FTIR). However, this technique suffers from relatively weak robustness in quantitative determination and, until recently, difficulties in separating carbonyls from other carboxylics (Blando et al., 2001; Maria et al., 2002). Recent developments in the FTIR approaches for OA (Russell et al., 2009; Liu et al., 2009) have however greatly improved the separation of these two functional groups. In the past decade, quantitative results were also achieved using proton nuclear magnetic resonance $\left({ }^{1} \mathrm{H}-\mathrm{NMR}\right)$ for the analysis of the carboxylic and carbonyl functional groups (Decesari et al., 2000; Moretti et al., 2008), and using solid-state ${ }^{13} \mathrm{C}$-NMR for the determination of carboxylic acids (Sannigraphi et al., 2007). The NMR methods still present difficulties for precise signal assignment in complex mixtures as well as high detection limits, especially using ${ }^{13} \mathrm{C}$-NMR. However, recent applications of ${ }^{1} \mathrm{H}$-NMR to the functional group chemical characterisation of atmospheric aerosol samples gave promising results for the study of the secondary organic aerosol (SOA) formation (Moretti et al., 2008) and for source attribution of marine, biomass burning, and SOA impacted atmospheric aerosols (Decesari et al., 2007).

Recently, tandem mass spectrometry (MS/MS) was applied to develop quantitative methods for the analysis of carboxylics (R-COOH), carbonyl (R-CO-R'), and nitro (R$\mathrm{NO}_{2}$ ) functional groups (Dron et al., 2007, 2008a, b). These MS/MS methods combine high sensitivity and good accuracy, and additionally make it possible to obtain an apparent molecular weight profile of the compounds bearing the functional group under study. In the present study, these analytical methods are applied to characterise the carboxylic, carbonyl, and nitro content of various aerosols. We studied some major sources of fine organic aerosol, i.e. vehicular exhaust, wood combustion, and SOA formed through photooxidation of $o$-xylene under laboratory conditions. On the other hand, we investigated the functionalisation of ambient atmospheric aerosols collected in a suburban site of an alpine valley in winter (Chamonix, France). All of these types of aerosols are compared in terms of molecular weight profiles, functional group distributions, and functionalisation rates. Finally, further interpretations regarding the influence of combustion processes and the use of the results for source apportionment of the atmospheric aerosol are also discussed and evaluated.

\section{Experimental}

\subsection{Sampling sites and conditions}

Samples from various experiments and field campaigns were studied; the sampling conditions and the analyses performed on the sample series are synthesised in Table 1.

\subsubsection{Secondary organic aerosols from $o$-xylene photooxidation}

A series of 4 secondary organic aerosol (SOA) samples were collected during $o$-xylene photooxidation experiments initiated with HONO, in the EUPHORE simulation chamber (European Photoreactor, Valencia - Spain, Becker et al., 1996). Experiment A was carried out at high initial concentration levels in $o$-xylene and HONO (600 ppbv $o$-xylene, $150 \mathrm{ppbv}$ HONO). Two filters were collected during the whole time of experiment A which lasted for 04:15. Experiment B was carried out at moderate initial concentrations $(200 \mathrm{ppbv} o$ xylene, 100 ppbv HONO). Two samples were collected during the whole time of experiment B, which lasted for $5 \mathrm{~h}$ 50. Particles were collected on $47 \mathrm{~mm}$ quartz fiber filters (QM-A, Whatman) at a flow rate of $1.5 \mathrm{~m}^{3} \mathrm{~h}^{-1}$, downstream a charcoal-impregnated denuder used to remove the volatile organic compounds (Eatough et al., 1999).

\subsubsection{Emission sources aerosols}

Aerosols emitted by combustion of the same sets of wood in 3 different burning devices were studied. The sets of wood were composed of beechwood $\operatorname{logs}(50 \mathrm{~cm}$ long and at least $6 \mathrm{~cm}$ large) containing $16 \%$ relative humidity. The wood combustion devices were one recent and one old model heating stoves both used for personal heating and an indoor fireplace. In each cases, $47 \mathrm{~mm}$ quartz fiber filters (QMA, Whatman) were collected at reduced and nominal (optimal) combustion efficiencies. These 6 aerosol samples were collected in the chimney outlets on the roofs of residential homes, through a heated tube $\left(125^{\circ} \mathrm{C}\right)$ at a flow rate of $1 \mathrm{~m}^{3} \mathrm{~h}^{-1}$ and during $6 \mathrm{~h}$.

Organic aerosol emitted by road traffic in a roadway tunnel was also considered. A full description of the sampling site and the sample collection procedures has been presented in El Haddad et al. (2009). Briefly, the sampling site was located in a French roadway tunnel (Tunnel, Marseilles) where heavy-duty trucks are prohibited and speed is limited to $50 \mathrm{~km} \mathrm{~h}^{-1}$. $\mathrm{PM}_{2.5}$ and $\mathrm{PM}_{10}$ samples were collected on two separate days, on $150 \mathrm{~mm}$ quartz fiber filters (QM-A, 
Table 1. Overview of the samples under study: analyses performed, sampling conditions and number of filters collected $(N)$ for each series.

\begin{tabular}{|c|c|c|c|}
\hline Samples and analyses & Sampling conditions & Filter collection & $N$ \\
\hline \multicolumn{4}{|l|}{ Urban background } \\
\hline Functional group & & $\mathrm{PM}_{10}, 12 \mathrm{~h}$ at $30 \mathrm{~m}^{3} \mathrm{~h}^{-1}$ & 11 \\
\hline Organic speciation & Chamonix, Dec 2007 & $\mathrm{PM}_{10}, 12 \mathrm{~h}$ at $30 \mathrm{~m}^{3} \mathrm{~h}^{-1}$ & 4 \\
\hline $\mathrm{OC} / \mathrm{EC}$ & & $\mathrm{PM}_{10}, 12 \mathrm{~h}$ at $1.5 \mathrm{~m}^{3} \mathrm{~h}^{-1}$ & 11 \\
\hline \multicolumn{4}{|l|}{ Vehicular emissions } \\
\hline Functional group, OC/EC & Marseille (tunnel) & $\begin{array}{l}\mathrm{PM}_{2.5}, 1 \mathrm{~h} \text { at } 30 \mathrm{~m}^{3} \mathrm{~h}^{-1} \\
\mathrm{PM}_{10}, 0.5 \mathrm{~h} \text { at } 30 \mathrm{~m}^{3} \mathrm{~h}^{-1}\end{array}$ & $\begin{array}{l}2^{\mathrm{a}} \\
2^{\mathrm{a}}\end{array}$ \\
\hline \multicolumn{4}{|l|}{ Wood combustion } \\
\hline Functional group & $\begin{array}{l}\text { old heating stove } \\
\text { recent heating stove } \\
\text { indoor fireplace }\end{array}$ & $\begin{array}{l}\mathrm{PM}_{10}, 6 \mathrm{~h} \text { at } 1 \mathrm{~m}^{3} \mathrm{~h}^{-1} \\
\mathrm{PM}_{10}, 6 \mathrm{~h} \text { at } 1 \mathrm{~m}^{3} \mathrm{~h}^{-1} \\
\mathrm{PM}_{10}, 6 \mathrm{~h} \text { at } 1 \mathrm{~m}^{3} \mathrm{~h}^{-1}\end{array}$ & $\begin{array}{l}2 \\
2 \\
2\end{array}$ \\
\hline \multicolumn{4}{|c|}{ Photooxidation experiment A } \\
\hline Functional group, OC/EC & $\begin{array}{l}\text { EUPHORE } \\
x y l e n e=600 \mathrm{ppb} \\
\text { HONO=150 ppb }\end{array}$ & $\mathrm{PM}_{2.5}, 4 \mathrm{~h} 15$ at $1.5 \mathrm{~m}^{3} \mathrm{~h}^{-1}$ & 2 \\
\hline \multicolumn{4}{|c|}{ Photooxidation experiment $B$} \\
\hline Functional group, OC/EC & $\begin{array}{l}\text { EUPHORE } \\
x y l e n e=200 p p b \\
\text { HONO=100 ppb }\end{array}$ & $\mathrm{PM}_{2.5}, 5 \mathrm{~h} 50$ at $1.5 \mathrm{~m}^{3} \mathrm{~h}^{-1}$ & 2 \\
\hline
\end{tabular}

${ }^{\text {a }}$ Composite of 12 different filters for each two $\mathrm{PM}_{2.5}$ samples and composite of 9 different filters for each two $\mathrm{PM}_{10}$ samples.

Whatman) by means of a DA-80 high volume sampler operating at a flow rate of $30 \mathrm{~m}^{3} \mathrm{~h}^{-1}$. The final 4 samples assigned to functional group determination were two separate combinations of $12 \mathrm{PM}_{2.5}$ filters and two separate combinations of $9 \mathrm{PM}_{10}$ filters, all collected between 07:00 a.m. and 08:00 p.m., therefore reflecting whole day emissions in the roadway tunnel, i.e. including both fluid and dense traffic episodes.

\subsubsection{Urban background aerosols}

Eleven consecutive samples were collected at an urban background site located in the Chamonix alpine valley (France) from 11 to 18 December 2007. The sampling site (Clos de l'Ours) has been described by Marchand et al. (2004). The Chamonix valley is narrow and surrounded by elevated mountains reaching 3000 to $4800 \mathrm{~m}$ above sea level (ma.s.l.) and is characterised by some of the steepest slopes in the Alps. The field campaign was conducted during an atmospheric pollution event characterised by high concentrations in $\mathrm{PM}_{10}$ (avg. $35 \mu \mathrm{g} \mathrm{m}^{-3}$, max. $100 \mu \mathrm{g} \mathrm{m}^{-3}$ ), NO (avg. $107 \mathrm{ppb}$, max. 640 ppb) and $\mathrm{NO}_{2}$ (avg. $71 \mathrm{ppb}$, max. $177 \mathrm{ppb}$ ) associated with low temperatures (avg. $-11.2^{\circ} \mathrm{C}$, $\min .-15.6^{\circ} \mathrm{C}$, $\max .-3.5 \mathrm{~min}$. C) and strong inversion layers.
$\mathrm{PM}_{10}$ were colleted on $150 \mathrm{~mm}$ quartz fiber filters (QM-A, Whatman) using a DA-80 high volume sampler $\left(30 \mathrm{~m}^{3} \mathrm{~h}^{-1}\right)$. The sampling was split in $12 \mathrm{~h}$ periods, from 06:00 a.m. to 06:00 p.m. (UTC) for daytime samples, and from 06:00 p.m. to 06:00 a.m. (UTC) for nighttime samples. The filters collected during the 11 and 12 December 2007 nights were put together in order to perform both functional groups and organic tracers analyses on the same filters, as well as $12 / 12$ and 13/12 day filters, $15 / 12$ and 16/12 night filters, and 16/12 and $17 / 12$ day filters. Another set of filters dedicated to OC and EC measurements were collected on Whatman QM-A at a flow rate of $1.5 \mathrm{~m}^{3} \mathrm{~h}^{-1}$ on the same time basis as the filters assigned for functional group determination. All filters used in this study were previously fired during $2 \mathrm{~h}$ at $500^{\circ} \mathrm{C}$ to lower the blank levels. All samples were stored at $-18^{\circ} \mathrm{C}$ in aluminium foil sealed in polyethylene bags until analysis.

\subsection{Functional group analyses}

The functional group analyses were carried out on a triple quadrupole mass spectrometer (Varian 1200L) equipped with an atmospheric pressure chemical ionisation (APCI) source and a high-performance liquid chromatography device (HPLC, Varian Prostar 210). The analytic techniques enabled the quantitative determination of the carboxylic (R- 
$\mathrm{COOH})$, carbonyls (R-CO- $\left.\mathrm{R}^{\prime}\right)$, and nitro $\left(\mathrm{R}-\mathrm{NO}_{2}\right)$ functional groups. They are based on the ability of the functional groups under study to lose a specific neutral molecular fragment (neutral loss scanning) or to produce a characteristic ion (precursor ion scanning) in the collision cell. As the fragmentation is affected by the molecular structure of each compound, the calibration is based on reference mixtures containing 16 (nitro groups), 24 (carbonyl groups) or 31 (carboxylic groups) compounds of various chemical structures and including mono and poly functional molecules. For each functional group, 25 reference mixtures of equal total concentrations in terms of functional groups were analysed. For each of these mixtures, the individual compound concentrations were determined randomly. The relative standard deviations (RSD) of the responses of the different calibration mixtures were in the range $10-20 \%$. This particular calibration procedure involving a statistical analysis of reference mixtures attested its reliability when applied to complex mixtures (Dron et al., 2007, 2008a, b). Mass spectra were recorded between $\mathrm{m} / \mathrm{z} 115$ and $\mathrm{m} / \mathrm{z}, 800$, except for the photooxidation experiments which were limited in the high masses to $m / z 600$. Calibration samples were analyzed within each sequence. Filter blanks were checked for each functional group determination and the results were all below detection limits.

The filters were extracted using an accelerated solvent extractor (ASE, Dionex) with a solvent mixture of methanol/hexane $(2: 1, v / v$, HPLC-grade from SigmaAldrich) and under the following conditions: $100^{\circ} \mathrm{C}$ and 100 bar during $5 \mathrm{~min}$ static time. The extracts were then evaporated to a volume of $0.5 \mathrm{~mL}$ at room temperature and under a gentle stream of nitrogen by means of an automatic concentrator (TurboVap II). The samples were finally diluted with methanol to a final volume of $3.5 \mathrm{~mL}$.

A $300 \mu \mathrm{L}$ fraction of the extracts was first submitted to the derivatisation of the carboxylic functional groups into their corresponding methyl esters, by adding $300 \mu \mathrm{L}$ of a boron trifluoride methanolic solution $\left(\mathrm{BF}_{3} /\right.$ methanol $14 \%, v / v$, Sigma-Aldrich) and heating for $2 \mathrm{~h}$ at $70^{\circ} \mathrm{C}$. The sample was then directly injected, i.e. without chromatographic separation, into the APCI chamber at a flow rate of $0.5 \mathrm{~mL} \mathrm{~min}^{-1}$, and the analysis was performed by recording the total ion current (TIC) measured by scanning the neutral loss of methanol $\left(\mathrm{CH}_{3} \mathrm{OH}, 32 \mathrm{amu}\right)$ from the fragmentation of the protonated methyl esters. In order to avoid any interference or unwanted compounds, a mass spectrum obtained by neutral loss scanning of $32 \mathrm{amu}$ (NL 32) was also recorded before derivatisation, and the corresponding signal was subtracted from the one recorded after derivatisation (Dron et al., 2007).

The determination of the carbonyl functional groups, i.e. aldehyde and ketone groups, was carried out after derivatisation with pentafluorophenylhydrazine ( $\mathrm{PFPH}$, Sigma-Aldrich). $150 \mu \mathrm{L}$ of a $0.1 \mathrm{M}$ methanolic solution of PFPH were added to $450 \mu \mathrm{L}$ of the initial sample extract, and the mixture was left to react for $18 \mathrm{~h}$ at room temperature. The analysis was then performed by injecting directly the solution into the APCI chamber at a flow rate of $0.5 \mathrm{~mL} \mathrm{~min}^{-1}$, and monitoring the neutral loss of $181 \mathrm{amu}$ (NL 181) from the fragmentation of the protonated hydrazone derivatives. A mass spectrum of the same sample obtained by NL 181 before derivatisation was recorded and subtracted from the spectrum obtained after the PFPH derivatisation (Dron et al., 2008a).

A final fraction of the sample extract was analyzed in order to determine the concentration in nitro functional groups. The sample was directly injected in the ionisation source at a flow rate of $0.5 \mathrm{~mL} \mathrm{~min}^{-1}$, negatively ionised, and the nitro compounds were simply determined by monitoring the precursor ions of the $\mathrm{NO}_{2}^{-}$product ion, $m / z 46$ (PAR 46) (Dron et al., 2008b).

The detection limits of the analytical procedures were $0.005 \mathrm{mM}, 0.004 \mathrm{mM}$, and $0.001 \mathrm{mM}$ for carboxylic acids, carbonyls, and nitros, respectively. According to the $30 \mathrm{~m}^{3} \mathrm{~h}^{-1}$ flow rate during $12 \mathrm{~h}$ sampling conditions and a sample volume of $3.5 \mathrm{~mL}$, these detection limits corresponded to atmospheric concentrations of $0.05 \mathrm{nmol} \mathrm{m}^{-3}$, $0.04 \mathrm{nmol} \mathrm{m}^{-3}$, and $0.01 \mathrm{nmol} \mathrm{m}^{-3}$ for carboxylic, carbonyl, and nitro functional groups, respectively. Functionalisation rates, expressed in \% of OC, can also be calculated using Eq. (1),

Functionalisation rate $(\%)=([$ functional group $] /[\mathrm{OC}]) \cdot 100$

where [functional group] is the molar concentration of the concerned functional group and $[\mathrm{OC}]$ the molar concentration of $\mathrm{OC}$ in the aerosol, both expressed in $\mathrm{mol} \mathrm{m}^{-3}$. In terms of OC functionalisation rates, the detection limits could be converted to $0.04 \%, 0.04 \%$ and $0.01 \%$ of OC for a sample presenting an $\mathrm{OC}$ concentration of $1 \mu \mathrm{g} \mathrm{m}^{-3}$. These detection limits were 10 times and 100 times lower than the ones reported in the literature using H-NMR for carboxylic (Tagliavini et al., 2006) and carbonyl moieties (Moretti et al., 2008), respectively. Quantitative functional group analysis of nitro moieties $\left(\mathrm{R}-\mathrm{NO}_{2}\right)$ was not reported in OA since Gordon et al. (1988) and was only performed using FT-IR until the development of our quantitative MS/MS method (Dron et al., 2008b). In the present study, OC concentrations ranged in Chamonix from 9 to $34 \mu \mathrm{g} \mathrm{m}^{-3}$ (Table 2) leading to actual detection limits below $0.001 \%$ in terms of functionalisation rates in this case.

\subsection{Organic tracers}

Four composite samples, representative of 4 days among the 6 days of the sampling period in Chamonix were solvent extracted and analysed by gas chromatography-mass spectrometry (GC-MS, Thermo Trace GC 2000 coupled to a Polaris $\mathrm{Q}$ ion trap mass spectrometer), following the recommendation of the Desert Research Institute for the analysis of semivolatile organic compounds (DRI, 2003). Before extraction, 
Table 2. Carboxylic, carbonyl and nitro functional groups molar concentrations $\left(\mathrm{nmol} \mathrm{m} \mathrm{m}^{-3}\right.$ ), corresponding functionalisation rates (\%) and OC $\left(\mu \mathrm{g} \mathrm{m}^{-3}\right)$ measured in the different types of atmospheric aerosols: urban background, road traffic and wood combustion emission sources, and SOA formation from $o$-xylene photooxidation.

\begin{tabular}{|c|c|c|c|c|}
\hline & $\mathrm{R}-\mathrm{COOH}$ & R-CO-R' & $\mathrm{R}-\mathrm{NO}_{2}$ & $\begin{array}{r}\mathbf{O C}\left(\mu \mathrm{g} \mathrm{m}^{-3}\right) \\
\text { mean (range) }\end{array}$ \\
\hline $\begin{array}{l}\text { Urban background, Chamonix } \\
\text { molar mean }\left(\mathrm{nmol} \mathrm{m}^{-3}\right) \\
\text { molar range }\left(\mathrm{nmol} \mathrm{m}^{-3}\right) \\
\text { functionalisation mean }(\%) \\
\text { functionalisation range }(\%)\end{array}$ & $\begin{array}{r}36.3 \\
14.7-54.7 \\
2.1 \\
1.6-3.1\end{array}$ & $\begin{array}{r}7.57 \\
4.19-10.8 \\
0.5 \\
0.3-0.6\end{array}$ & $\begin{array}{r}1.95 \\
1.19-2.38 \\
0.1 \\
0.1-0.2\end{array}$ & $21.0(9.01-33.9)$ \\
\hline $\begin{array}{l}\text { Vehicular emissions } \\
\text { molar mean }\left(\mathrm{nmol} \mathrm{m} \mathrm{m}^{-3}\right) \\
\text { molar range }\left(\mathrm{nmol} \mathrm{m}^{-3}\right) \\
\text { functionalisation mean }(\%) \\
\text { functionalisation range }(\%)\end{array}$ & $\begin{array}{r}38.4 \\
29.1-55.7 \\
0.8 \\
0.6-1.0\end{array}$ & $\begin{array}{r}15.7 \\
10.7-21.7 \\
0.3 \\
0.3-0.5\end{array}$ & $\begin{array}{r}37.1 \\
27.6-50.2 \\
0.8 \\
0.5-1.1\end{array}$ & $54.7(34.5-68.2)$ \\
\hline $\begin{array}{l}\text { Wood combustion } \\
\text { molar mean }\left(\mathrm{nmol} \mathrm{m}^{-3}\right) \\
\text { molar range }\left(\mathrm{nmol} \mathrm{m} \mathrm{m}^{-3}\right) \\
\text { functionalisation mean }(\%) \\
\text { functionalisation range }(\%)\end{array}$ & $\begin{array}{r}4990 \\
505-12540 \\
- \\
-\end{array}$ & $\begin{array}{r}853 \\
159-3480 \\
- \\
-\end{array}$ & $\begin{array}{r}68.4 \\
\text { n.d. }-183 \\
- \\
-\end{array}$ & no data \\
\hline $\begin{array}{l}\text { Photooxidation experiment } \mathbf{A} \\
\text { molar mean }\left(\mathrm{nmol} \mathrm{m} \mathrm{m}^{-3}\right) \\
\text { molar range }\left(\mathrm{nmol} \mathrm{m} \mathrm{m}^{-3}\right) \\
\text { functionalisation mean }(\%) \\
\text { functionalisation range }(\%)\end{array}$ & $\begin{array}{r}154 \\
133-174 \\
2.0 \\
2.0-2.0\end{array}$ & $\begin{array}{r}521 \\
428-612 \\
6.7 \\
6.4-7.0\end{array}$ & $\begin{array}{r}38.2 \\
23.8-52.6 \\
0.4 \\
0.3-0.6\end{array}$ & $84.0(54.4-114)^{b}$ \\
\hline $\begin{array}{l}\text { Photooxidation experiment B } \\
\text { molar mean }\left(\mathrm{nmol} \mathrm{m}^{-3}\right) \\
\text { molar range }\left(\mathrm{nmol} \mathrm{m} \mathrm{m}^{-3}\right) \\
\text { functionalisation mean }(\%) \\
\text { functionalisation range }(\%)\end{array}$ & $\begin{array}{r}28.8 \\
28.5-29.1 \\
2.0 \\
1.7-2.4\end{array}$ & $\begin{array}{r}115 \\
101-130 \\
8.3 \\
5.8-10.7\end{array}$ & $\begin{array}{r}4.85 \\
4.16-5.53 \\
0.3 \\
0.3-0.3\end{array}$ & $15.9(13.5-18.3)^{b}$ \\
\hline
\end{tabular}

n.d. $=$ not detected

a Association of $\mathrm{PM}_{10}$ and $\mathrm{PM}_{2.5}$ samples (El Haddad et al., 2009).

${ }^{\mathrm{b}} \mathrm{PM}\left(\mu \mathrm{g} \mathrm{m}^{-3}\right)$ measured by TEOM (1400 A, R and P), and converted to OC assuming that the particles were exclusively constituted of organic materials, and that OM/OC=1.75 on the basis of the structure of the main compounds detected in similar photooxidation experiments (Forstner et al., 1997; Aiken et al., 2008).

samples were spiked with known amounts of isotope-labelled standards, tetracosane-d50 and cholesterol-d6. They were extracted by ASE with a dichloromethane/acetone mixture $(1: 1, v / v)$ using the same temperature and pressure conditions as previously. One fraction was directly injected for the quantification of the hopanes and steranes. A second fraction $(50 \mu \mathrm{L})$ was derivatised before the GC/MS analysis with $50 \mu \mathrm{L}$ of N,O-bis(trimethylsilyl)-trifluoroacetamide (BSTFA, Sigma-Aldrich) containing 10\% trimethylchlorosilane (TMCS) in order to convert the organic acids and alcohols into their trimethylsilyl esters and ethers, respectively. The two fractions were analysed using the same GCMS conditions, i.e. electron impact ionisation at $70 \mathrm{eV}$ and chromatographic separation on a TR-5MS capillary column (ThermoElectron). The quantification of the organic compounds was performed using authentic standards, and the compounds for which no authentic standard was available were quantified using the response factor of compounds with analogous chemical structures (for a detailed list of the standards: see Table 4, Sect. 3.3.). Field blank filters were treated with the same procedure. The overall procedure is further detailed in (El Haddad et al., 2009).

\section{$2.4 \quad \mathrm{OC} / \mathrm{EC}$}

Samples collected at Chamonix and in the roadway tunnel were analyzed for EC and OC using the Thermo-Optical Transmission (TOT) method with a Sunset Lab analyzer. The newly developed EUSAAR2 temperature program proposed by Cavalli et al. (2008) was used. The EUSAAR2 method includes temperature up to $570^{\circ} \mathrm{C}$ for the analysis of $\mathrm{OC}$ in $100 \% \mathrm{He}$, and up to $870^{\circ} \mathrm{C}$ for the analysis of $\mathrm{EC}$ in $98 \%$ $\mathrm{He}+2 \% \mathrm{O}_{2}$. 


\section{Results and discussion}

The quantitative results of the 3 functional groups measurements are presented in Table 2, as molar concentrations and functionalisation rates for all the samples under study. The carboxylic (R-COOH), carbonyl (R-CO-R'), and nitro $\left(\mathrm{R}-\mathrm{NO}_{2}\right)$ functionalisation rates are also reported in Fig. 1, showing that the relative contributions of the three functional groups are significantly different from one aerosol source to another.

\subsection{Functional groups fingerprints of aerosol sources}

The primary vehicular exhaust particles collected in the tunnel are characterised by a low functionalisation rate ranging from 1.7 to $2.2 \%$ of OC (Table 2). As a result, only one atom of carbon out of 49 on average bears one of the functional groups under study. More in detail, vehicular exhaust OA presents an important nitro content (0.5 to $1.1 \%$ ) which equals the carboxylic functionalisation rate (0.6 to $1 \%)$. The carbonyl functionalisation rate is twice lower, ranging from 0.3 to $0.5 \%$ (Table 2). Compared to the other samples, the large nitro content may be linked to the high temperatures of the combustion processes occuring in the vehicle engines (Matthews, 1980; Eberhardt et al., 2003) and can be partially attributed to nitro-PAHs, previously identified in diesel exhaust OA (Heeb et al., 2008). The low content in functional groups containing oxygen atoms (carbonyl and carboxylic acid) is also consistent with the moderate water soluble organic carbon (WSOC) fraction measured, which accounts for $20 \%$ of the OC measured inside the tunnel (El Haddad et al., 2009) and with the hydrophobic propreties of fresh vehicular exhaust soot particles previously described in the literature (Weingartner et al., 1997).

In contrast, wood combustion particles are characterised by high carboxylic and carbonyl concentrations which can reach $12 \mu \mathrm{mol} \mathrm{m}^{-3}$ and $3.5 \mu \mathrm{mol} \mathrm{m}^{-3}$, respectively (Table 1). These concentrations are 2 to 3 orders of magnitude larger than those measured inside the tunnel, highlighting the large emissions of organic matter produced by wood combustion compared to vehicular exhaust (Schauer et al., 1999, 2001, 2002). It also shows the significant fraction of highly polar organic compounds (essentially lignin pyrolysis products for the carboxylic and carbonyl moieties, Nolte et al., 2001) and humic like substances (Graber and Rudich, 2006) associated with these emissions. An important variability of the functional groups concentrations is also observed according to the combustion conditions. As no OC data were available for wood smoke samples, this variability is observed through the carbonyl-to-carboxylic and nitro-to-carboxylic ratios (Table 3). Nitro functional groups are not detected in the particles emitted by wood combustion in open fire, for both combustion efficiencies, while the particles formed in the heating stoves (old and recent) present nitro-to-carboxylic ratios between 0.01 and 0.1 . For comparison purpose, this ratio is

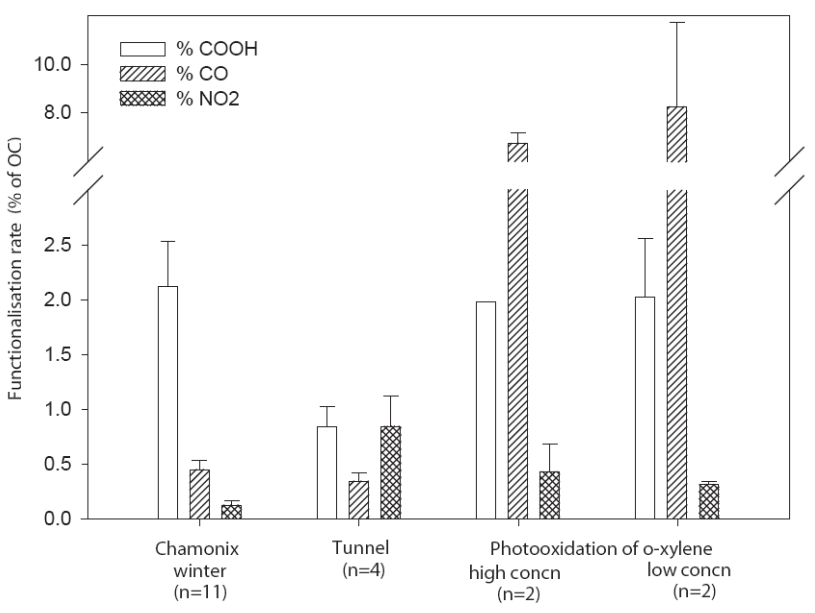

Fig. 1. Functionalisation rates measured in the different aerosols under study. Concentrations are given in terms of functional group molar content normalised to the OC molar content (expressed in \% of OC). Error bars represent the standard deviations calculated for each sample series.

close to 1 for the tunnel aerosol (Table 3 ). This result confirms the influence of the combustion processes on the nitro functional group contents since open fires present the lowest combustion temperature while vehicular emissions are issued from high temperature fuel combustion processes. However, no clear trend is observed between nominal and reduced operating conditions for nitro-to-carboxylic ratios in the cases of heating stoves. The carbonyl-to-carboxylic ratio presents relevant characteristics as well. In the wood combustion samples, it is systematically and significantly higher for nominal combustion efficiencies than for reduced combustion conditions. In addition, at high efficiencies, the ratios are significantly lower for open fire emissions than in the heating stoves. Finally, the highest carbonyl-to-carboxylic ratio is observed for the roadway traffic emissions. Consequently, increasing the combustion efficiency would possibly favour the production of nitro and carbonyl groups compared to carboxylic acids. This confirms that primary combustion aerosols may be characterised by their functional group contents according to the combustion process involved.

SOA formed through photooxidation of $o$-xylene exhibit a very different functional group fingerprint. For these experiments, OC was deduced from PM concentrations assuming that PM is only constituted of organic matter (OM). On the basis of the structure of the main compounds detected in similar photooxidation experiments (Forstner et al., 1997; Aiken et al., 2008), a ratio $\mathrm{OM} / \mathrm{OC}=1.75$ was used in this study to estimate the OC concentrations. Whereas the functional groups molar concentrations reported in Table 2 are very dependant upon the initial concentrations in $o$-xylene and HONO, the functionalisation rates are similar for the 2 experimental conditions under study. This shows that the 
Table 3. Carbonyl to carboxylic and nitro to carboxylic molar ratios in different wood combustion devices and in the road traffic emissions collected in the tunnel, Marseille (France).

\begin{tabular}{|c|c|c|}
\hline & $\begin{array}{l}\mathrm{R}-\mathrm{CO}-\mathrm{R}^{\prime} / \\
\mathrm{R}-\mathrm{COOH}\end{array}$ & $\begin{array}{c}\mathrm{R}-\mathrm{NO}_{2} / \\
\mathrm{R}-\mathrm{COOH}\end{array}$ \\
\hline \multicolumn{3}{|l|}{ Wood combustion ${ }^{a}$} \\
\hline Recent stove, nominal & 0.29 & 0.01 \\
\hline Recent stove, reduced & 0.15 & 0.05 \\
\hline Old stove, nominal & 0.32 & 0.10 \\
\hline Old stove, reduced & 0.04 & 0.01 \\
\hline Open fire, nominal & 0.19 & n.d. \\
\hline Open fire, reduced & 0.14 & n.d. \\
\hline Tunnel roadway (mean, $n=4$ ) & $0.41 \pm 0.19$ & $0.97 \pm 0.49$ \\
\hline
\end{tabular}

n.d. $=\mathrm{R}-\mathrm{NO}_{2}$ not detected.

a For each wood combustion experiment, one sample was analyzed and the applicable variability is limited to the analytical deviations: $12,19.5$ and $18 \%$ for carboxylics, carbonyls and nitros, respectively (Dron et al., 2007, 2008a, b).

initial concentrations of $o$-xylene and HONO have no significant influence on the functionalisation of the SOA formed, at least in the range of concentrations covered in this study. The total functionalisation rates of the $o$-xylene photooxidation SOA are particularly high, with approximately $1 / 9$ OC atoms in experiment $\mathrm{A}$ and 1/11 OC atoms in experiment $\mathrm{B}$ functionalised by carboxylic, carbonyl or nitro groups. The SOA samples are strongly dominated by carbonyl groups (Fig. 1), which represent about $75 \%$ of all the functional groups determined here. This result is in good agreement with gas phase photooxidation chemistry of $\mathrm{VOC} / \mathrm{NO}_{\mathrm{x}}$ sytems (Calvert et al., 2002; Camredon et al., 2007). These characteristics are very specific to SOA compared to the two types of primary aerosol observed in our study.

\subsection{Chamonix urban background aerosol}

The total functionalisation rates, considering the three functional groups under study, range from 2 to $4 \%$ for the particles collected in Chamonix (Table 2). All the samples are dominated by carboxylic moieties, with carbonyls and nitro groups being 2 to 5 times less concentrated (Fig. 2). Moretti et al. (2008) measured by H-NMR similar molar concentrations in urban background aerosols collected in Bologna (Italy) in the May-June period. They reported total carboxylic concentrations ranging from 5 to $50 \mathrm{nmol} \mathrm{m}^{-3}$ and total carbonyl concentrations from 4 to $35 \mathrm{nmol} \mathrm{m}^{-3}$. The corresponding functionalisation rates were from 6 to $20 \%$ and from $<3$ to $11 \%$ of water soluble organic carbon (WSOC) for carboxylic acids and carbonyls, respectively. This is higher than what is measured in the present study, but it shall be noted that WSOC is a very variable fraction of OC, generally representing 30 to $80 \%$ of OC and, in addition, includes most exclusively the oxygenated fraction of OC (Decesari et al., 2006; Duarte et al., 2007; Salma et al.,
2007). The differences may also result from the sampling period and location especially considering the singularity of the valley of Chamonix during winter characterised by high primary emissions from both road traffic and residential heating (Marchand et al., 2004) associated with unfavourable conditions for SOA formation and chemical aging due to low temperatures $\left(-3.5\right.$ to $\left.-15.6{ }^{\circ} \mathrm{C}\right)$, low solar irradiance, and a lack of long range transport of the aerosol. The relatively low carbonyl content found in 20 Chamonix OA compared to the high carbonyl functionalisation rates measured for the photooxidation experiments ( 6 to $11 \%$ ) supports the assumption that the Chamonix winter OA is mainly of primary origin, considering the abundance of carbonyl as a marker for SOA. In a recent study conduced at Mexico City, FTIR functional groups analyses have pointed out low functionalisation rates for carbonyls (0 to 1.5\%) (Liu et al., 2009) whereas SOA, mainly from biogenic origin, was a major fraction of $\mathrm{OA}$ (Stone et al., 2008; Hodzic et al., 2009). This result suggests that carbonyl abundance can not be considered as an univocal marker of SOA. It highlights the strong need to complete the functional group fingerprints database with other SOA precursors (particularly biogenic VOC) and, most probably, that the chemical nature of OA can not be resumed to only first generation oxidation products especially in highly photochemically active environments.

However, significant variations are observed during the sampling period for the carboxylic and carbonyl concentrations, with ranges from 14.7 to $54.7 \mathrm{nmol} \mathrm{m}^{-3}$ and from 4.2 to $10.8 \mathrm{nmol} \mathrm{m}^{-3}$, respectively. These variations are linearly correlated with OC concentrations, and the correlation coefficients are $R^{2}=0.84$ and $R^{2}=0.79(n=11)$, respectively. These observations are illustrated in Fig. 2, representing the evolution of the atmospheric concentrations for the three functional groups, together with the OC concentration during the whole sampling period. This result implies that the carboxylic acid and the carbonyl functionalisation rates are fairly constant during the sampling period and that no significant differences are observed between day and night samples. Therefore, we can assume that the sources of the aerosol are homogeneous over the measurement period and that the photooxidation processes do not significantly change the composition of the organic fraction of the aerosol in the conditions encountered during the sampling campaign. The carboxylic and carbonyl concentrations measured here are then principally subjected to the evolution of OC concentrations. To a lesser extent, these correlations highlight the reliability of the functional group analytical procedures recently developed.

The nitro functional group is the less represented in the Chamonix aerosols and the concentrations are relatively stable, ranging from 1.2 to $2.4 \mathrm{nmol} \mathrm{m}^{-3}$. Such stability induces a lack of linear correlation with the OC content. In these conditions, the functionalisation rate for nitro groups also presents significant variations during the sampling period, ranging from 0.07 to $0.23 \%$. Although a fraction of 


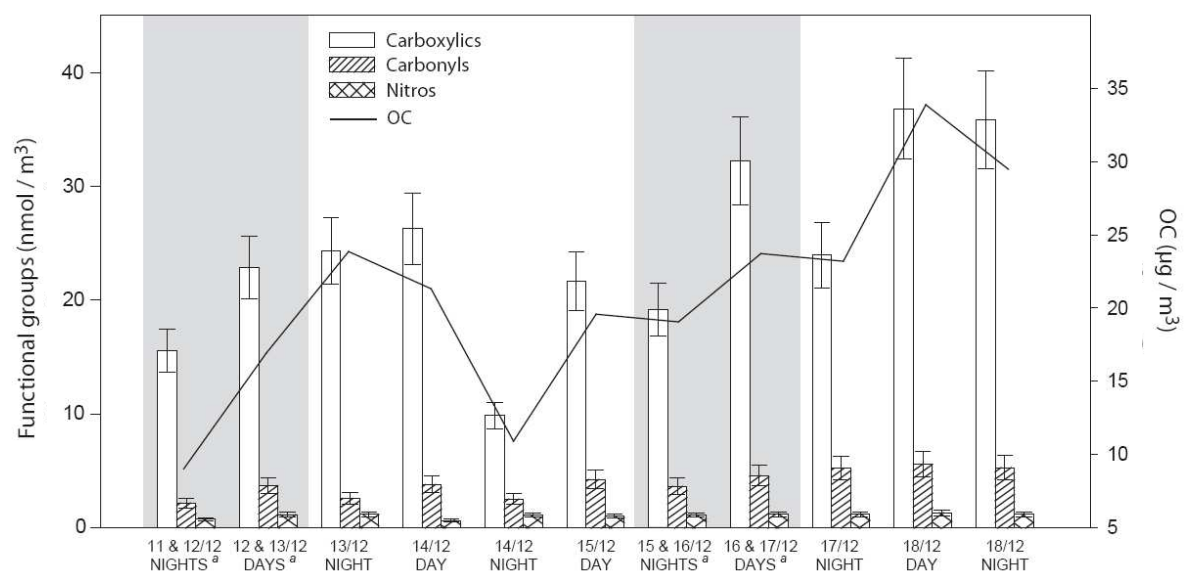

Fig. 2. Carboxylic, carbonyl and nitro functional groups and OC atmospheric concentrations during the Chamonix sampling campaign, in December 2007. The filters were collected following night (18:00 h to 06:00 h local time) and day periods (06:00 $\mathrm{h}$ to 18:00 $\mathrm{h} \mathrm{local}$ time). Error bars represent the analytical deviations. The grey backgrounds outline the samples also used for determination of organic tracers. Error bars correspond to the analytical RSD (carboxylics: $12 \%$, carbonyls: $20 \%$, nitros: $20 \%$ ).

${ }^{a}$ Composite samples of the filters collected at the indicated dates, see text for details (Sect. 2.1.3).

the nitro compounds may be formed through radical-initiated reactions of organic compounds (Reisen and Arey, 2005), no correlation between $\mathrm{NO}_{\mathrm{x}}$ and nitro functionalisation rates was further observed. This suggests a primary origin of the nitro compounds measured in this study.

\subsection{Sources discrimination using functional group fingerprints}

As discussed above, the functionalisation rates for carboxylic acids, carbonyl, and nitro functional groups reveal strong differences according to the nature of the aerosol source. Therefore, it is interesting to test the ability of these functional groups fingerprints to discriminate sources of ambient organic aerosol. Samples from a narrow alpine valley during winter appear as an interesting case study since chemical aging can be neglected as a first approximation. In addition, vehicular emissions and wood combustion can be considered as the two principal primary sources of urban background aerosol in winter (Schauer and Cass, 2000; Zheng et al., 2002) and in an alpine valley (Marchand et al., 2004; Sandradewi et al., 2008). In a first approach, the functional groups fingerprint derived from the photooxidation of $o$-xylene is considered here as a fair approximation for SOA in such conditions (high $\mathrm{NO}_{\mathrm{x}}$ concentrations: $178.4 \mathrm{ppb}$ in average, low $\mathrm{O}_{3}$ concentrations: $3.2 \mathrm{ppb}$ in average, and low biogenic activity, as measured during our sampling campaign) (Finlayson-Pitts and Pitts, 2000; Atkinson and Arey, 2003). The functional groups fingerprints of the 3 sources under study and of the urban background aerosol collected in Chamonix, in winter 2007, can be visualised altogether according to their carbonyl-to-carboxylic and nitroto-carboxylic functional group ratios, as presented in Fig. 3.

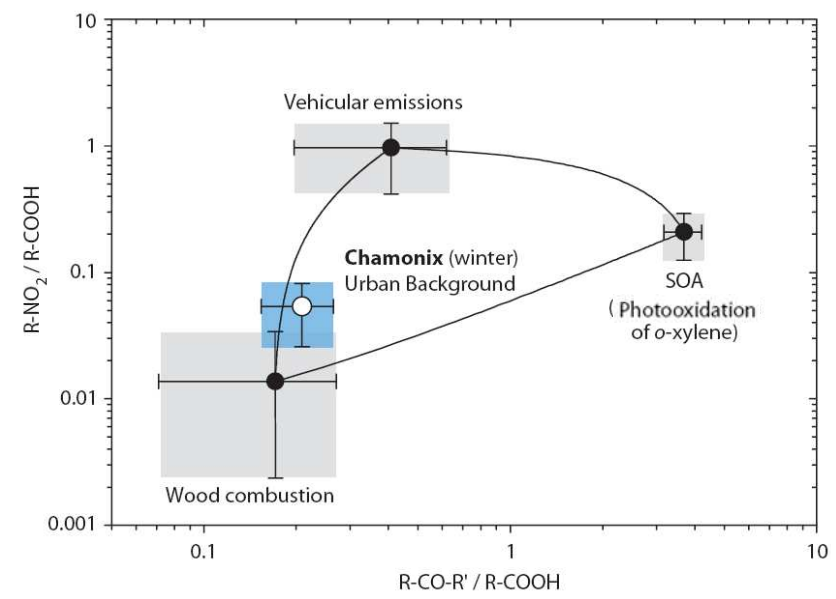

Fig. 3. Average $\mathrm{R}-\mathrm{NO}_{2} / \mathrm{R}-\mathrm{COOH}$ and $\mathrm{R}-\mathrm{CO}-\mathrm{R}^{\prime} / \mathrm{R}-\mathrm{COOH}$ ratios (logarithmic scales) obtained for the 3 aerosol sources (black circles) and for the Chamonix urban background aerosol (white circle). The 3 points corresponding to the aerosol sources are connected by solid curves. Error bars represent the standard deviations calculated for each sample series, $n=6$ for wood combustion, $n=4$ for road traffic, $n=4$ for $o$-xylene photooxidation (materialised as grey boxes for the aerosol sources), and $n=11$ for the Chamonix aerosol (materialised as blue box).

The functional group ratios of the 3 aerosol sources are clearly separated, forming a triangle (points are connected by solid curves in Fig. 3) in which the point corresponding to the Chamonix functional group fingerprint is included. Assuming that the functional groups fingerprints of the three sources described in this study are representative of the emissions and aerosol formation processes in the Chamonix valley, 
and that no heterogeneous chemical process has significantly modified the composition of the organic fraction during the aerosol atmospheric residence time, a large contribution of wood burning to the ambient OA can be assessed. This is in agreement with the wide use of wood combustion in the valley and with previous results obtained in the same location (Marchand et al., 2004; Jaffrezo et al., 2005; Aymoz et al., 2007). The predominance of the wood combustion contribution in such environments is also in good agreement with the source apportionment studies performed in similar alpine valleys during winter by Favez et al. (2010) and by Sandradewi et al. (2008), the latter attributing $88 \%$ of OA to wood burning emissions. The contribution of vehicular exhaust emissions to $\mathrm{OC}$ appears very low in comparison to wood combustion. Finally, regarding the functional groups ratio-to-ratio plot, the SOA contribution appears negligible. This observation is in agreement with recent studies estimating the contribution of SOA may drop below $10 \%$ of the total OC in wintertime in US locations (Shivastrava et al., 2007; Lewandowski et al., 2008).

The results obtained in the present study must still be taken with care, due to the hypothesis that the 3 aerosol sources considered must represent all the major sources of the OC in the Chamonix valley. The chemical profile of the vehicular emissions in Chamonix can be different from the one of the Marseilles tunnel traffic, as the wood combustion emissions may be affected by the wood nature (Schauer et al., 2001; Oros and Simoneit, 2001; Fine et al., 2002) and the combustion processes (Table 2). Finally, considering $o$-xylene photooxidation in presence of $\mathrm{NO}_{\mathrm{x}}$ as representative of the total urban background SOA in terms of functional group distributions cannot be assessed, as it is the first quantitative functional group determination of SOA produced in simulation chamber.

In order to assess the relevance of functional groups ratios as a diagnostic tool to discriminate sources, a source apportionment approach using organic markers has been performed. Table 4 reports the average concentrations of the selected organic markers quantified in the Chamonix aerosol during the same sampling campaign, including hopanes and steranes emitted by vehicular emissions and different wood combustion markers such as levoglucosan, retene, sterols, and guaiacyl and syringyl derivatives. The contributions of these two major sources $\left(\mathrm{OC}_{\text {source }}\right.$, expressed in $\left.\mu \mathrm{g} \mathrm{m}^{-3}\right)$ can be calculated following Eq. (2),

$\mathrm{OC}_{\text {source }}=[\mathrm{M}] /([\mathrm{M}] / \mathrm{OC})_{\text {source }}$

where $[\mathrm{M}]$ is the concentration of a source specific marker determined in the ambient samples (expressed in $\mathrm{ng} \mathrm{m}^{-3}$ ) and $([\mathrm{M}] / \mathrm{OC})_{\text {source }}$ is the fractional abundance of the considered organic marker to $\mathrm{OC}$ in the source aerosol (expressed in $\left.\mathrm{mg} \mathrm{g}^{-1}\right)$.

Because of its ubiquity in all wood combustion aerosols, the levoglucosan is widely used for estimating the amount of $\mathrm{OC}$ from wood or biomass combustions in the ambient aerosol. The (levoglucosan/OC) wood ratios determined by Fine et al. (2002) is quite variable according to burning conditions and wood types. Typically, a ratio of $42 \mathrm{mg} \mathrm{g}^{-1}$ is found for softwood combustion, while a higher ratio of $136 \mathrm{mg} \mathrm{g}^{-1}$ is found for hardwood combustion. The type of wood predominantly used for the combustion can be determined using the other wood combustion markers. The syringyl derivatives and $\beta$-sitosterol are found to a much greater extent in the hardwood smokes. Accordingly, a $(\beta \text {-sitosterol/OC })_{\text {wood }}$ ratio of $2.9 \mathrm{mg} \mathrm{g}^{-1}$ is reported for hardwood combustions, while a much lower ratio of $0.2 \mathrm{mg} \mathrm{g}^{-1}$ is reported for softwood combustions (Fine et al., 2002). In contrast, retene is an alteration product of the resin acids found in conifers (softwood), and is exclusively emitted from softwood combustions ((retene/OC) $)_{\text {softwood }}=5.1 \mathrm{mg} \mathrm{g}^{-1}$ ) (Fine et al., 2002). The high concentrations of syringyl derivatives and $\beta$-sitosterol ( $\beta$-sitosterol/OC $=2.3 \mathrm{mg} \mathrm{g}^{-1}$ ) and the low concentration of retene (retene/OC $=0.33 \mathrm{mg} \mathrm{g}^{-1}$ ) found in the samples from Chamonix suggest that the aerosol is mainly produced by hardwood combustion. The results presented for functional group determinations were obtained for beechwood (hardwood) combustion in various heating devices, and are thus well suited to estimate the wood combustion contribution in the Chamonix valley. Considering the average (levoglucosan/OC) ratio, the mean wood combustion contribution is estimated to $61 \%$ of $\mathrm{OC}\left(\mathrm{OC}_{\mathrm{wood}}=9.9 \mu \mathrm{g} \mathrm{m}^{-3}\right)$. Comparable contributions of wood combustion to OC (50-80\%) were found in winter using the same methodology, at background sites in Europe (Puxbaum et al., 2007; Favez et al., 2010). These results confirm the prominence of wood combustion in the Chamonix aerosol.

The contribution of the vehicular emissions to $\mathrm{OC}$ is calculated using Eq. (2) and hopane as a specific marker of vehicular emissions (Rogge et al., 1993). The same tunnel samples were used for functional groups analyses and for the determination of the (hopane/OC) road ratio of $0.206 \mathrm{mg} \mathrm{g}^{-1}$ (El Haddad et al., 2009). The average contribution of the vehicular emissions to the $\mathrm{OC}$ is estimated to $14 \%\left(\mathrm{OC}_{\text {vehicles }}=2.27 \mu \mathrm{g} \mathrm{m}^{-3}\right)$. The remaining OC $(20.2 \%)$ is attributed to the SOA contribution along with other minor primary sources.

The functional groups diagnostic ratios approach gives rather consistent results with the organic markers approach when estimating the wood combustion contribution. Nevertheless, these encouraging results obtained in source apportionment by MS/MS functional group analysis must be confirmed and supported by the study of additional aerosol sources and by longer atmospheric measurement series in various environments, especially during summer. Chemical aging of the aerosol must also be investigated in terms of modifications in the functionalisation rates. Recent studies have shown a rapid and significant evolution of the organic fraction of primary aerosol (wood combustion and diesel 
Table 4. Concentrations of organic tracers measured in the filter samples (average values, $\mathrm{ng} \mathrm{m}^{-3}$ ) collected in winter 2007 in Chamonix (France) and calculated contributions of wood combustion and road traffic emission sources (refer to text for the details of the contributions calculations).

\begin{tabular}{|c|c|c|c|c|c|}
\hline \multirow[b]{2}{*}{ compounds } & \multicolumn{5}{|c|}{ Organic compounds mean concentrations $\left[\mathrm{ng} \mathrm{m}^{-3}\right]$} \\
\hline & $\begin{array}{l}\text { Average } \\
\text { concentrations }\end{array}$ & Note & compounds & $\begin{array}{l}\text { Average } \\
\text { concentrations }\end{array}$ & Note \\
\hline \multicolumn{6}{|l|}{ steranes } \\
\hline $5 \alpha(\mathrm{H}), 14 \beta(\mathrm{H}), 17 \beta(\mathrm{H})$-Cholestane & $0.28 \pm 0.13$ & $\mathrm{~b}$ & $5 \alpha(\mathrm{H}), 14 \beta(\mathrm{H}), 17 \beta(\mathrm{H})$-Ergostane & $0.25 \pm 0.10$ & $\mathrm{~b}$ \\
\hline $5 \alpha(\mathrm{H}), 14 \alpha(\mathrm{H}), 17 \alpha(\mathrm{H})$-Cholestane & $0.42 \pm 0.18$ & $\mathrm{a}$ & $5 \alpha(\mathrm{H}), 14 \beta(\mathrm{H}), 17 \beta(\mathrm{H})$-Stigmastane & $0.52 \pm 0.20$ & $\mathrm{~b}$ \\
\hline \multicolumn{6}{|l|}{ hopanes } \\
\hline Trisnorneohopane & $0.34 \pm 0.19$ & $\mathrm{c}$ & $17 \alpha(\mathrm{H})-21 \beta(\mathrm{H})-22 \mathrm{~S}-$ Homohopane & $0.23 \pm 0.07$ & $\mathrm{c}$ \\
\hline $17 \alpha(\mathrm{H})$-Trisnorhopane & $0.33 \pm 0.15$ & $\mathrm{c}$ & $17 \alpha(\mathrm{H})-21 \beta(\mathrm{H})-22 \mathrm{R}-H o m o h o p a n e$ & $0.125 \pm 0.04$ & $\mathrm{c}$ \\
\hline $17 \alpha(\mathrm{H})-21 \beta(\mathrm{H})$-Norhopane & $0.72 \pm 0.30$ & $\mathrm{c}$ & $17 \alpha(\mathrm{H})-21 \beta(\mathrm{H})-22 \mathrm{~S}-$ Bishomohopane & $0.15 \pm 0.10$ & $\mathrm{c}$ \\
\hline $17 \alpha(\mathrm{H})-21 \beta(\mathrm{H})-$ Hopane & $0.59 \pm 0.18$ & $\mathrm{a},+$ & $17 \alpha(\mathrm{H})-21 \beta(\mathrm{H})-22 \mathrm{R}-\mathrm{Bishomohopane}$ & $0.07 \pm 0.05$ & $\mathrm{c}$ \\
\hline \multicolumn{6}{|l|}{ PAH } \\
\hline Retene & $5.2 \pm 1.6$ & $\mathrm{~d}$ & & & \\
\hline \multicolumn{6}{|l|}{ guaiacyls derivatives } \\
\hline Vanillin & $51 \pm 27$ & $\mathrm{a}$ & 3-Guaiacylpropanol & $17 \pm 4.8$ & $\mathrm{a}$ \\
\hline Acetovanillone & $11 \pm 4.7$ & a & Vanillic acid & $21 \pm 7.6$ & $\mathrm{a}$ \\
\hline Coniferyl aldehyde & $65 \pm 19$ & $\mathrm{a}$ & & & \\
\hline \multicolumn{6}{|l|}{ syringyls derivatives } \\
\hline Syringalaldehyde & $150 \pm 91$ & $\mathrm{a}$ & 3-Syringylpropanol & $7 \pm 6$ & $\mathrm{f}$ \\
\hline Acetosyringone & $67 \pm 23$ & $\mathrm{a}$ & Synapyl aldehyde & $61 \pm 56$ & $\mathrm{~g}$ \\
\hline Propionyl Syringol & $30 \pm 9$ & e & Syringic acid & $29 \pm 8$ & $\mathrm{~h}$ \\
\hline Syringyl acetone & $81 \pm 52$ & $\mathrm{e}$ & Homosyringic acid & $2.0 \pm 1.4$ & $\mathrm{~h}$ \\
\hline \multicolumn{6}{|l|}{ sugar anhydrides } \\
\hline Galactosan & $70 \pm 24$ & $\mathrm{i}$ & Mannosan & $140 \pm 50$ & $\mathrm{i}$ \\
\hline Levoglucosan & $1340 \pm 430$ & $\mathrm{a}, \ddagger$ & & & \\
\hline \multicolumn{6}{|l|}{ sterols } \\
\hline Cholesterol & $3.5 \pm 0.35$ & a & Stigmasterol & $3.0 \pm 0.21$ & $\mathrm{a}$ \\
\hline \multirow[t]{2}{*}{ Campesterol } & $3.1 \pm 0.45$ & $\mathrm{j}$ & $\beta$-Sitosterol & $37 \pm 7.5$ & a \\
\hline & \multicolumn{5}{|c|}{ Major mass concentration $\left[\mu \mathrm{g} \mathrm{m}^{-3}\right]$} \\
\hline \multirow[t]{2}{*}{$\mathrm{OC}^{*}$} & & $16 \pm 4.9$ & $\mathrm{PM}_{2.5} *$ & $31 \pm 9.1$ & \\
\hline & \multicolumn{3}{|c|}{ Sources contributions to OC $[\%]$} & & \\
\hline Wood combustion & & $61 \pm 14$ & & & \\
\hline Vehicular emissions & & $14 \pm 4$ & & & \\
\hline Other sources $* *$ & & $25 \pm 15$ & & & \\
\hline
\end{tabular}

(a-i) identification notes: the quantification of the organic compounds is based on the response factors of a - authentic standards, b $-20 \mathrm{R}, 5 \alpha(\mathrm{H}), 14 \alpha(\mathrm{H}), 17 \alpha(\mathrm{H})-\mathrm{cholestane}, \mathrm{c}-$ $17 \alpha(\mathrm{H})-21 \beta(\mathrm{H})$-hopane, $\mathrm{d}$ - phenanthrene, e - syringualdehyde, $\mathrm{f}$ - 3-Guaiacylpropanol, $\mathrm{g}$ - Coniferyl aldehyde, $\mathrm{h}$ - vanilic acid, $\mathrm{i}$ - Levoglucosan and $\mathrm{j}$ - average response factor of cholesterol and $\beta$-sitosterol.

$(+$ and $\ddagger)$ sources contribution determination notes: organic compounds used for the determination of the vehicular emissions contribution ( + ) and the wood combustion contribution (†).

* Average OC and PM determined for the composite samples on which the organic speciation analyses was carried on.

* Deduced from wood and road contributions assuming that the total of contributions is $100 \%$.

emissions) due to photooxidation processes (Sage et al., 2008; Grieshop et al., 2009; Favez et al., 2010). These chemical modifications can greatly affect the functional group distribution and thus the ability of functional groups to distinguish the aerosol sources.

\subsection{Apparent mass distributions of functional groups}

The mass spectra recorded are an additional source of information offered by APCI-MS/MS functional group analysis. They provide a visualisation of the apparent mass distribution of all the detected ions bearing the functional group 

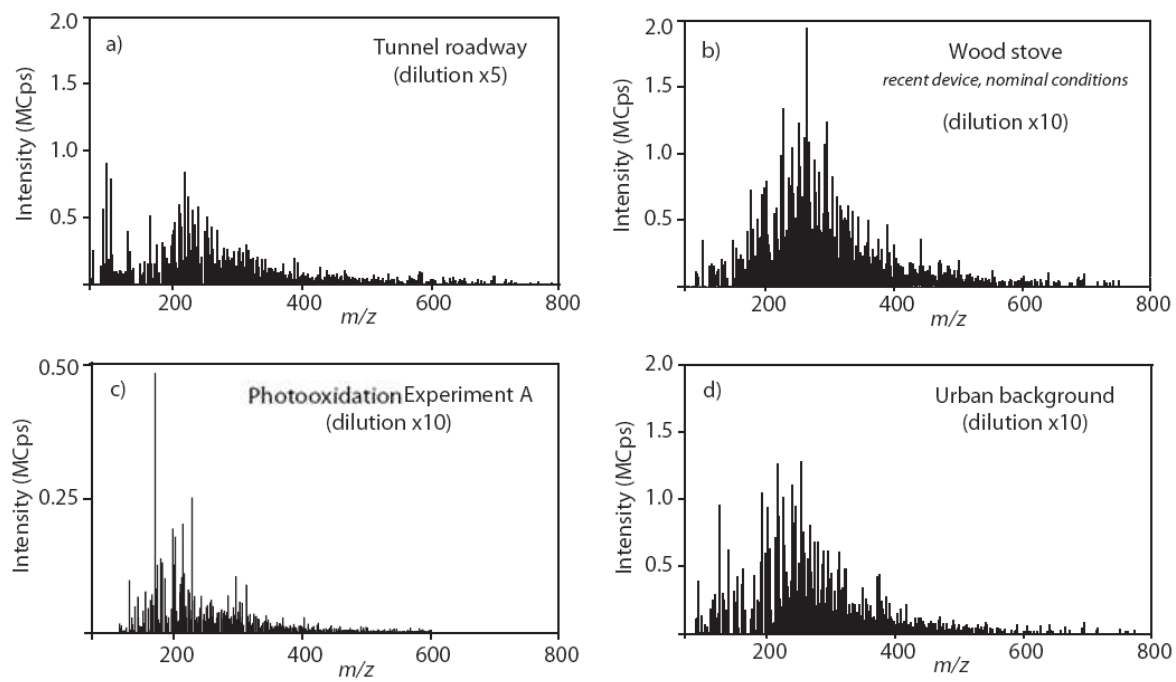

Fig. 4. Carboxylic acids mass spectra recorded by NL32 for (a) tunnel roadway, (b) wood combustion, (c) $o$-xylene photooxidation experiment at high initial concentration levels, and (d) urban background samples. As the mass spectra were not recorded during the same sequences, only comparisons based on mass profiles shall be considered, the signal intensities being strongly affected by day-to-day variations.

under study. Examples of mass spectra recorded in the NL 32 mode for the quantification of total carboxylic acids for each aerosol category are presented in Fig. 4. Their global aspects are quite similar, and the average molecular weights of the detected ions are around $m / z 200$ for the SOA and vehicular exhaust samples, and around $m / z 260$ for the wood combustion and Chamonix samples. A 15 amu subtraction is necessary to obtain the carboxylic molecular weight from the corresponding methyl ester derivatives. These results are particularly close to the $248 \mathrm{~g} \mathrm{~mol}^{-1}$ average molecular weight calculated by a thermodynamic method recently applied to a biomass burning aerosol (Asa-Awuku et al., 2008). Ions are detected at nearly every $\mathrm{m} / \mathrm{z}$ ratios in the vehicular exhaust, wood combustion, SOA and urban background aerosols (Fig. 4), attesting the extreme chemical complexity of OA. All of the aerosols studied here also present a large fraction of peaks above $m / z, 300$, which could characterise a large HULIS content (Dron, 2008).

This is consistent with the large unresolved fraction classically found in atmospheric OA often attributed to this type of compounds, constituting up to $30 \%$ of the total OC in ambient air (Hamilton et al., 2005; Feczko et al., 2007; Salma et al., 2007). Also, recent studies proposed wood combustion as a major source of HULIS (Lukacs et al., 2007; Asa-Awuku et al., 2008; Baduel et al., 2009). The samples from wood combustion and from Chamonix urban background contain the largest amounts of high molecular weight compounds, which is consistent with the results indicating wood combustion primary particles as the main component of the aerosol in the Chamonix Valley.
As for carboxylic acids, the mass spectra recorded for the determination of carbonyls and nitro groups are relatively similar in terms of apparent mass distributions for all samples. Carbonyls are also detected up to $\mathrm{m} / \mathrm{z} 500$, but nitro functional groups are not detected above $m / z$ 300. This indicates that the high molecular weight compounds encountered in atmospheric OA such as HULIS contain significant amounts of carboxylic and carbonyl groups. They do not present detectable levels of nitro functional groups, as reported by other studies pointing out that HULIS are mainly composed of oxygenated functional groups (Havers et al., 1998; Reinhardt et al., 2007) together with organosulfates $\left(\mathrm{R}-\mathrm{OSO}_{3}\right)$ and organonitrates $\left(\mathrm{R}-\mathrm{ONO}_{2}\right)$ (Reemtsma et al., 2006).

\section{Conclusions}

The MS/MS functional group analysis was applied to the characterisation of the OA from primary and secondary sources, and from an ambient aerosol. The detection limits and the good quantitative accuracy offered by the new MS/MS functional group analytical methods make them a powerful and complementary tool for the characterisation of the OA. In the present study, the carboxylic (R-COOH), carbonyl (R-CO-R') and nitro $\left(\mathrm{R}-\mathrm{NO}_{2}\right)$ functional groups could be detected at the $\mathrm{nmol} \mathrm{m}^{-3}$ level. Carboxylic acids represented about $2.0 \%$ of the organic carbon in the SOA and ambient samples, but only $0.8 \%$ in the vehicular emissions OA. The aerosol sources showed distinct functional groups distributions, in particular with a high carbonyl content in the $o$-xylene laboratory generated SOA (6 to $11 \%$ of OC) and a 
high nitro content in the vehicular emissions ( $0.8 \%$ of OC). These characteristics enabled the establishment of diagnostic functional group ratios. Then the source contributions of an ambient aerosol was evaluated and showed a good agreement with an organic tracer approach performed on the same samples.

The results presented here offer interesting perspectives in OA characterisation. The MS/MS functional group analysis methods are theoretically applicable to all chemical functional groups. For instance, the additional determination of hydroxyl (R-OH), organonitrates $\left(\mathrm{R}-\mathrm{ONO}_{2}\right)$ and organosulfates $\left(\mathrm{R}-\mathrm{OSO}_{3}\right)$ groups would provide very valuable compositional data and knowledge relative to the aerosol chemistry. Aerosol aging may also be investigated through the systematic measurement of functional groups in different locations and during significant time periods. The study of aerosol sources can also be completed with additional sources to provide improved accuracy in evaluating the source contributions of an ambient aerosol.

In addition to the quantitative results, the MS/MS technique for functional group determination provides a second type of information through the recorded mass spectra, as the molecular weight distribution of the detected compounds may reveal qualitatively the presence of humic-like substances in the sample under study.

Acknowledgements. This work has been supported by ADEME (Agence De l'Environnement et de la Maitrise de l'Energie) and by the "Region Provence Alpes Cote d'Azur" and the Ministry of the Environment of France through the research program PRIMEQUAL2 (grant no. 0001135, FORMES project) and the research grant for J. Dron. The authors also thank the Centre National de la Recherche Scientifique (CNRS) and the Institut National des Sciences de l'Univers (INSU) for their financial supports.

The authors also acknowledge the whole scientific group of the simulation chamber EUPHORE and the different partners involved in the EUPHORE experiments (LISA, CNRS-University of Créteil; and ICARE, CNRS Orléans).

The authors are finally thankful to the LCME laboratory (University of Savoie), the INERIS institute and the ATMO-PACA air quality survey association for their implications in the different sampling campaigns.

Edited by: L. M. Russell

\section{References}

Aiken, A. C., DeCarlo, P. F., Kroll, J. H., Worsnop, D. R., Huffman, J. A., Docherty, K. S., Ulbrich, I. M., Mohr, C., Kimmel, J. R., Sueper, D., Sun, Y., Zhang, Q., Trimborn, A., Northway, M., Ziemann, P. J., Canagaratna, M. R., Onasch, T. B., Alfarra, M. R., Prévôt, A. S. H., Dommen, J., Duplissy, J., Metzger, A., Baltensperger, U., and Jimenez, J. L.: O/C and OM/OC Ratios of Primary, Secondary, and Ambient Organic Aerosols with HighResolution Time-of-Flight Aerosol Mass Spectrometry, Environ. Sci. Technol., 42, 4478-4485, 2008.
Atkinson, R. and Arey, J.: Atmospheric degradation of volatile organic compounds, Chem. Rev., 103, 4605-4638, 2003.

Asa-Awuku, A., Sullivan, A. P., Hennigan, C. J., Weber, R. J., and Nenes, A.: Investigation of molar volume and surfactant characteristics of water-soluble organic compounds in biomass burning aerosol, Atmos. Chem. Phys., 8, 799-812, doi:10.5194/acp-8799-2008, 2008.

Aymoz, G., Jaffrezo, J. L., Chapuis, D., Cozic, J., and Maenhaut, W.: Seasonal variation of $\mathrm{PM}_{10}$ main constituents in two valleys of the French Alps. I: EC/OC fractions, Atmos. Chem. Phys., 7, 661-675, doi:10.5194/acp-7-661-2007, 2007.

Baduel, C., Voisin, D., and Jaffrezo, J.-L.: Water-soluble atmospheric HULIS in urban environments, Atmos. Chem. Phys. Discuss., 9, 21561-21579, doi:10.5194/acpd-9-21561-2009, 2009.

Becker, K.H., Hjorth, J., Laverdet, G., Millan, M. M., Platt, U., Toupance, G., and Wildt, J.: Design and technical development of the European photoreactor and first experimental results, EV5V-CT92-0059, 1996.

Blando, J. D., Porcja, R. J., and Turpin, B. J.: Issues in the quantitation of functional groups by FTIR spectroscopic analysis of impactor-collected aerosols samples, Aerosol Sci. Technol., 35, 899-908, 2001.

Calvert, J. G., Atkinson, R., Becker, K. H., Kamens, R. M., Seinfeld, J. H., Wallington, T. J., and Yarwood, G.: The mechanisms of atmospheric oxidation of aromatic hydrocarbons, Oxford University Press: Oxford, UK, 2002.

Camredon, M., Aumont, B., Lee-Taylor, J., and Madronich, S.: The SOA/VOC/NO $\mathrm{NO}_{\mathrm{x}}$ system: an explicit model of secondary organic aerosol formation, Atmos. Chem. Phys., 7, 5599-5610, doi:10.5194/acp-7-5599-2007, 2007.

Cao, J. J., Wu, F., Chow, J. C., Lee, S. C., Li, Y., Chen, S. W., An, Z. S., Fung, K. K., Watson, J. G., Zhu, C. S., and Liu, S. X.: Characterization and source apportionment of atmospheric organic and elemental carbon during fall and winter of 2003 in Xi'an, China, Atmos. Chem. Phys., 5, 3127-3137, doi:10.5194/acp-53127-2005, 2005.

Cappiello, A., De Simoni, E., Fiorucci, C., Mangani, F., Palma, P., Trufelli, H., Decesari, S., Facchini, M. C., and Fuzzi, S.: Molecular characterization of the water-soluble organic compounds in fogwater by ESIMS/MS, Environ. Sci. Technol., 37, 1229-1240, 2003.

Cavalli, F., Viana, M., Yttri, K. E., Genberg, J., and Putaud, J.P.: Toward a standardised thermal-optical protocol for measuring atmospheric organic and elemental carbon: the EUSAAR protocol, Atmos. Meas. Tech., 3, 79-89, doi:10.5194/amt-3-79-2010, 2010.

Decesari, S., Facchini, M.C., Fuzzi, S., and Tagliavini E.: Characterization of water-soluble organic compounds in atmospheric aerosol: A new approach, J. Geophys. Res., 105, 1481-1489, 2000.

Decesari, S., Fuzzi, S., Facchini, M. C., Mircea, M., Emblico, L., Cavalli, F., Maenhaut, W., Chi, X., Schkolnik, G., Falkovich, A., Rudich, Y., Claeys, M., Pashynska, V., Vas, G., Kourtchev, I., Vermeylen, R., Hoffer, A., Andreae, M. O., Tagliavini, E., Moretti, F., and Artaxo, P.: Characterization of the organic composition of aerosols from Rondnia, Brazil, during the LBASMOCC 2002 experiment and its representation through model compounds, Atmos. Chem. Phys., 6, 375-402, doi:10.5194/acp6-375-2006, 2006. 
Decesari, S., Mircea, M., Cavalli, F., Fuzzi, S., Moretti, F., Tagliavini, E., and Facchini, M. C.: Source attribution of watersoluble organic aerosol by nuclear magnetic resonance spectroscopy, Environ. Sci. Technol., 41, 2479-2484, 2007.

Donahue, N. M., Robinson, A. L., Pandis, S. N.: Atmospheric organic particulate matter: From smoke to secondary organic aerosol, Atmos. Environ., 43, 94-106, 2009.

DRI Desert Research Institute: Analysis of Semi-volatile Organic Compound by GC/MS, DRI Standard Operating Procedure, 125, 2003.

Dron, J., Eyglunent, G., Temime-Roussel, B., Marchand, N., and Wortham, H.: Carboxylic acid functional group analysis using constant neutral loss scanning-mass spectrometry, Anal. Chim. Acta, 605, 61-69, 2007.

Dron, J., Zheng, W., Marchand, N., and Wortham, H.: New method to determine the total carbonyl functional group content in extractable particulate organic matter by tandem mass spectrometry, J. Mass Spectrom., 43, 1089-1098, 2008a.

Dron, J., Abidi, E., El Haddad, I., Marchand, N., and Wortham, H.: Precursor ion scanning-mass spectrometry for the determination of the nitro functional groups in atmospheric particulate organic matter, Anal. Chim. Acta, 618, 184-195, 2008b.

Dron, J.: Analyse fonctionnelle par spectrométrie de masse tandem: application aux aérosols organiques atmosphériques, $\mathrm{PhD}$ thesis, Université de Provence, 2008.

Duarte, R., Santos, E., Pio, C., and Duarte, A.: Comparison of structural features of water-soluble organic matter from atmospheric aerosols with those of aquatic humic substances, Atmos. Environ., 41, 8100-8113, 2007.

Eberhardt, O., Grünert, A., and Ballschmiter, K.: Simulation of the atmospheric pattern of alkyl nitrates by the reaction of alkanes with NO2/HNO3, Geophys. Res. Abstr., 5, 11001, 2003.

El Haddad, I., Marchand, N., Dron, J., Temime-Roussel, B., Quivet, E., Wortham, H., Jaffrezo, J.-L., Baduel, C., Voisin, D., Besombes, J.-L., and Gille, G.: Comprehensive primary particulate organic characterization of vehicular exhaust emissions in France, Atmos. Environ., 43, 6190-6198, 2009.

Eatough, D. J., Obeidi, F., Pang, Y., Ding, Y., Eatough, N. L., and Wilson, W. E.: Integrated and real-time diffusion denuder sample for $\mathrm{PM}_{2.5}$, Atmos. Environ., 33, 2835-2844, 1999.

Favez, O., El Haddad, I., Piot, C., Boréave, A., Abidi, E., Marchand, N., Jaffrezo, J.-L., Besombes, J.-L., Personnaz, M.-B., Sciare, J., Wortham, H., George, C., and D'Anna, B.: Inter-comparison of source apportionment models for the estimation of wood burning aerosols during wintertime in an Alpine city (Grenoble, France), Atmos. Chem. Phys. Discuss., 10, 559-613, doi:10.5194/acpd10-559-2010, 2010.

Feczko, T., Puxbaum, H., Kasper-Giebl, A., Handler, M., Limbeck, A., Gelencsér, A., Pio, C., Preunkert, S., and Legrand, M. Determination of water and alkaline extractable atmospheric humiclike substances with the TU Vienna HULIS analyzer in samples from six background sites in Europe, J. Geophys. Res., 112, D23S10, doi:10.1029/2006JD008331, 2007.

Fine, P. M., Cass, G. R., and Simoneit, B. R. T.: Chemical characterization of fine particle emissions from the fireplace combustion of woods grown in the southern United States, Environ. Sci. Technol., 36, 1442-1451, 2002.

Finlayson-Pitts, B. J. and Pitts, J. N.: Chemistry of the upper and lower atmosphere: Theory, experiments, and applications, Aca- demic Press Editors (Elsevier) San Diego CA, USA, 2000.

Forstner, H. J. L., Flagan, R. C., and Seinfeld, J. H.: Secondary organic aerosol from the photooxidation of aromatic hydrocarbons: molecular composition, Environ. Sci. Technol., 31, 1345-1358, 1997.

Fuzzi, S., Andreae, M. O., Huebert, B. J., Kulmala, M., Bond, T. C., Boy, M., Doherty, S. J., Guenther, A., Kanakidou, M., Kawamura, K., Kerminen, V.-M., Lohmann, U., Russell, L. M., and Pöschl, U.: Critical assessment of the current state of scientific knowledge, terminology, and research needs concerning the role of organic aerosols in the atmosphere, climate, and global change, Atmos. Chem. Phys., 6, 2017-2038, doi:10.5194/acp-62017-2006, 2006.

Gordon, R. J., Nirupam, T. J., and Brij, S. P.: Characterization of aerosol organics by diffuse reflectance Fourier Transform Infrared spectroscopy, Environ. Sci. Technol., 22, 672-677, 1988.

Graber, E. R. and Rudich, Y.: Atmospheric HULIS: How humiclike are they? A comprehensive and critical review, Atmos. Chem. Phys., 6, 729-753, doi:10.5194/acp-6-729-2006, 2006.

Grieshop, A. P., Logue, J. M., Donahue, N. M., and Robinson, A. L.: Laboratory investigation of photochemical oxidation of organic aerosol from wood fires 1: measurement and simulation of organic aerosol evolution, Atmos. Chem. Phys., 9, 1263-1277, doi:10.5194/acp-9-1263-2009, 2009.

Hallquist, M., Wenger, J. C., Baltensperger, U., Rudich, Y., Simpson, D., Claeys, M., Dommen, J., Donahue, N. M., George, C., Goldstein, A. H., Hamilton, J. F., Herrmann, H., Hoffmann, T., Iinuma, Y., Jang, M., Jenkin, M. E., Jimenez, J. L., Kiendler-Scharr, A., Maenhaut, W., McFiggans, G., Mentel, Th. F., Monod, A., Prévôt, A. S. H., Seinfeld, J. H., Surratt, J. D., Szmigielski, R., and Wildt, J.: The formation, properties and impact of secondary organic aerosol: current and emerging issues, Atmos. Chem. Phys., 9, 5155-5236, doi:10.5194/acp-95155-2009, 2009.

Hamilton, J. F., Webb, P. J., Lewis, A. C., and Reviejo, M. M.: Quantifying small molecules in secondary organic aerosol formed during the photo-oxidation of toluene with hydroxy radicals, Atmos. Environ., 39, 7263-7275, 2005.

Havers, N., Burba, P., Lambert, J., and Klockow, D.: Spectroscopic characterization of humic-like substances in airborne particulate matter, J. Atmos. Chem., 29, 45-54, 1998.

Heeb, N. V, Schmid, P., Kohler, M., Gujer, E., Zennegg, M., Wenger, D., Wichser, A., Ulrich, A., Gfeller, U., Honegger, P., Zeyer, K., Emmenegger, L., Petermann, J.-L., Czerwinski, J., Mosimann, T., Kasper, M., and Mayer, A.: Secondary effects of catalytic diesel particulate filters: conversion of PAHs versus formation of nitro-PAHs, Environ. Sci. Technol., 42, 3773-3779, 2008.

Hodzic, A., Jimenez, J. L., Madronich, S., Aiken, A. C., Bessagnet, B., Curci, G., Fast, J., Lamarque, J.-F., Onasch, T. B., Roux, G., Schauer, J. J., Stone, E. A., and Ulbrich, I. M.: Modeling organic aerosols during MILAGRO: importance of biogenic secondary organic aerosols, Atmos. Chem. Phys., 9, 6949-6981, doi:10.5194/acp-9-6949-2009, 2009.

IPCC (International Panel on Climate Change): Forster, P., Ramaswamy, V., Artaxo, P., Berntsen, T., Betts, R., Fahey, D. W., Haywood, J., Lean, J., Lowe, D. C., Myhre, G., Nganga, J., Prinn, R., Raga, G., Schulz, M., and Van Dorland, R.: Changes in atmospheric constituents and in radiative forcing, in: climate 
change 2007: the physical science basis, contribution of working group I to the fourth assessment report of the Intergovernmental Panel on Climate Change. Cambridge University Press, Cambridge, United Kingdom and New York, NY, USA, 2007.

Jaffrezo, J.-L., Aymoz, G., Delaval, C., and Cozic, J.: Seasonal variations of the water soluble organic carbon mass fraction of aerosol in two valleys of the French Alps, Atmos. Chem. Phys., 5, 2809-2821, doi:10.5194/acp-5-2809-2005, 2005.

Kanakidou, M., Seinfeld, J. H., Pandis, S. N., Barnes, I., Dentener, F. J., Facchini, M. C., Van Dingenen, R., Ervens, B., Nenes, A., Nielsen, C. J., Swietlicki, E., Putaud, J. P., Balkanski, Y., Fuzzi, S., Horth, J., Moortgat, G. K., Winterhalter, R., Myhre, C. E. L., Tsigaridis, K., Vignati, E., Stephanou, E. G., and Wilson, J.: Organic aerosol and global climate modelling: a review, Atmos. Chem. Phys., 5, 1053-1123, doi:10.5194/acp-5-1053-2005, 2005.

Lanz, V. A., Alfarra, M. R., Baltensperger, U., Buchmann, B., Hueglin, C., Szidat, S., Wehrli, M. N., Wacker, L., Weimer, S., Caseiro, A., Puxbaum, H., and Prevot, A. S. H.: Source attribution of submicron organic aerosols during wintertime inversions by advanced factor analysis of aerosol mass spectra, Environ. Sci. Technol., 42, 214-220, 2008.

Lewandowski, M., Jaoui, M., Offenberg, J. H., Kleindienst, T., Edney, E. O., Sheesley, R. J., and Schauer, J. J.: Primary and secondary contributions to ambient PM in the Midwestern United States, Environ. Sci. Technol., 42, 3303-3309, 2008.

Liu, S., Takahama, S., Russell, L. M., Gilardoni, S., and Baumgardner, D.: Oxygenated organic functional groups and their sources in single and submicron organic particles in MILAGRO 2006 campaign, Atmos. Chem. Phys., 9, 6849-6863, doi:10.5194/acp9-6849-2009, 2009.

Lukacs, H., Gelencsér, A., Hammer, S., Puxbaum, H., Pio, C., Legrand, M., Kasper-Giebl, A., Handler, M., Limbeck, A., Simpson, D., and Preunkert, S.: Seasonal trends and possible sources of brown carbon based on 2-year aerosol measurement at six sites in Europe, J. Geophys. Res., 112, D23S18, doi:10.1029/2006JD008151, 2007.

Marchand, N., Besombes, J. L., Chevron, N., Masclet, P., Aymoz, G., and Jaffrezo, J. L.: Polycyclic aromatic hydrocarbons (PAHs) in the atmospheres of two French alpine valleys: sources and temporal patterns, Atmos. Chem. Phys., 4, 11671181, doi:10.5194/acp-4-1167-2004, 2004.

Maria, S. F., Russell, L. M., Turpin, B. J., and Porcja, R. J.: FTIR measurements of functional groups and organic mass in aerosol samples over the Caribbean, Atmos. Environ., 36, 5185-5196, 2002.

Matthews, R. D.: Estimated permissible levels, ambient concentrations, and adverse effects of the nitrogenous products of combustion: The cyanides, nitro-olefins, and nitroparaffins, J. Combust. Toxicol., 7, 157-172, 1980.

Moretti, F., Tagliavini, E., Decesari, S., Facchini, M. C., Rinaldi, M., and Fuzzi, S.: NMR determination of total carbonyls and carboxyls: a tool for tracing the evolution of atmospheric oxidized organic aerosols, Environ. Sci. Technol., 42, 4844-4849, 2008.

Nolte, C. G., Schauer, J. J., Cass G. R., and Simoneit B. R. T.: Highly polar organic compounds in wood smoke and in the ambient atmosphere, Environ. Sci. Technol., 35, 1912-1919, 2001.

Oros, D. R. and Simoneit, B. R. T.: Identification and emission factors of molecular tracers in organic aerosols from biomass burning Part 1. Temperate climate conifers, Appl. Geochem., 16, 1513-1544, 2001.

Pio, C., Alves, C. A., and Duarte, A. C.: Organic components of aerosols in a forested area of central Greece, Atmos. Environ., 35, 389-401, 2001.

Puxbaum, H., Caseiro, A., Sanchez-Ochoa, A., Kasper-Giebl, A., Claeys, M., Gelencsér, A., Legrand, M., Preunkert, S., and Pio, C.: Levoglucosan levels at background sites in Europe for assessing the impact of biomass combustion on the European aerosol background, J. Geophys. Res., 112, D23S05, doi:10.1029/2006JD008114, 2007.

Reemstma, T., These, A., Venkatachari, P., Xia, X., Hopke, P. K., Springer, A., and Linscheid, M.: Identification of fulvic acids and sulphated and nitrated analogues in atmospheric aerosol by electrospray ionization Fourier transform ion cyclotron resonance mass spectrometry, Anal. Chem., 78, 8299-8304, 2006.

Reinhardt, A., Emmenegger, C., Gerrits, B., Panse, C., Dommen, J., Baltensperger, U., Zenobi, R., and Kalberer, M.: Ultrahigh resolution and accurate mass measurements as a tool to characterize oligomers in secondary organic aerosols, Anal. Chem., 79, 4074-4082, 2007.

Reisen, F. and Arey, J.: Atmospheric reactions influence seasonal PAH and nitro-PAH concentrations in the Los Angeles basin, Environ. Sci. Technol., 39, 64-73, 2005.

Rogge, W. F., Hildemann, L. M., Mazurek, M. A., Cass, G. R., and Simoneit, B. R. T.: Sources of fine organic aerosols 2. Noncatalyst and catalyst-equipped automobiles and heavy-duty diesel trucks, Environ. Sci. Technol., 27, 636-651, 1993.

Ruellan, S. and Cachier, H. Characterisation of fresh particulate vehicular exhausts near a Paris high flow road, Atmos. Environ., 35, 453-468, 2001.

Russell, L. M., Takahama, S., Liu, S., Hawkins, L. N., Covert, D. S., Quinn, P. K., and Bates, T. S.: Oxygenated fraction and mass of organic aerosol from direct emission and atmospheric processing measured on the R/V Ronald Brown during TEXAQS/GoMACCS 2006, J. Geophys. Res., 114, D00F05, doi:10.1029/2008JD011275, 2009.

Sage, A. M., Weitkamp, E. A., Robinson, A. L., and Donahue, N. M.: Evolving mass spectra of the oxidized component of organic aerosol: results from aerosol mass spectrometer analyses of aged diesel emissions, Atmos. Chem. Phys., 8, 1139-1152, doi:10.5194/acp-8-1139-2008, 2008.

Salma, I., Ocskay, R., Chi, X., and Maenhaut, W.: Sampling artefacts, concentration and chemical composition of fine watersoluble organic carbon and humic-like substances in a continental urban atmospheric environment, Atmos. Environ., 41, 41064118, 2007.

Sandradewi, J., Prévôt, A. S. H., Szidat, S., Perron, N., Alfarra, M. R., Lanz, V. A., Weingartner, E., and Baltensperger, U.: Using aerosol light absorption measurements for the quantitative determination of wood burning and traffic emission contributions to particulate matter, Environ. Sci. Technol., 42, 3316-3323, 2008.

Sannigrahi, P., Sullivan, A. P., Weber, R. J., and Ingall, E. D.: Characterization of water-soluble organic carbon in urban atmospheric aerosols using solid-state 13C NMR spectroscopy, Environ. Sci. Technol., 40, 666-672, 2006.

Schauer, J. J., Kleeman, M., Cass, G. R., and Simoneit, B. R. T.: Measurement of Emissions from Air Pollution Sources. 2. C1 
through C30 Organic Compounds from Medium Duty Diesel Trucks, Environ. Sci. Technol., 10, 1578-1587, 1999.

Schauer, J. J., Kleeman, M. J., Cass, G. R., and Simoneit, B. R. T.: Measurement of emissions from air pollution sources 2. C1 through C30 organic compounds from medium duty diesel trucks, Environ. Sci. Technol., 33, 1578-1587, 1999.

Schauer, J. J. and Cass, G. R.: Source apportionment of wintertime gas-phase and particle-phase air pollutants using organic compounds as tracers, Environ. Sci. Technol., 34, 1821-1832, 2000.

Schauer, J. J., Kleeman, M. J., Cass, G. R., and Simoneit, B. R. T.: Measurement of emissions from air pollution sources 3. C1-C29 organic compounds from fireplace combustion of wood, Environ. Sci. Technol., 35, 1716-1728, 2001.

Schauer, J. J., Kleeman, M. J., Cass, G. R., and Simoneit, B. R. T.: Measurement of Emissions from Air Pollution Sources. 5. C1-C32 Organic Compounds from Gasoline-Powered Motor Vehicles, Environ. Sci. Technol., 6, 1169-1180, 2002.

Shrivastava, M. K., Subramanian, R., Rogge, W. F., and Robinson, A. L.: Sources of organic aerosol: Positive matrix factorization of molecular marker data and comparison of results from different source apportionment models, Atmos. Environ., 41, 93539369, 2007.
Stone, E. A., Snyder, D. C., Sheesley, R. J., Sullivan, A. P., Weber, R. J., and Schauer, J. J.: Source apportionment of fine organic aerosol in Mexico City during the MILAGRO experiment 2006, Atmos. Chem. Phys., 8, 1249-1259, doi:10.5194/acp-81249-2008, 2008.

Tagliavini, E., Moretti, F., Decesari, S., Facchini, M. C., Fuzzi, S., and Maenhaut, W.: Functional group analysis by $\mathrm{H}$ $\mathrm{NMR} / \mathrm{chemical}$ derivatization for the characterization of organic aerosol from the SMOCC field campaign, Atmos. Chem. Phys., 6, 1003-1019, doi:10.5194/acp-6-1003-2006, 2006.

Weingartner, E., Burtscher, H., and Baltensperger, U.: Hygroscopic properties of carbon and diesel soot particles, Atmos. Environ., 31, 2311-2327, 1997.

Zheng, M., Cass, G. R., Schauer, J. J., and Edgerton, E. S.: Source apportionment of PM2.5 in the south-eastern United States using solvent-extractable organic compounds as tracers, Environ. Sci. Technol., 36, 2361-2371, 2002. 